\title{
DESIGNATION OF PRINCIPAL WATER-SUPPLY AQUIFERS IN MINNESOTA
}

U. S. GEOLOGICAL SURVEY

WATER-RESOURCES INVESTIGATIONS 81-51

PREPARED IN COOPERATION WITH THE

U. S. ENVIRONMENTAL PROTECTION AGENCY

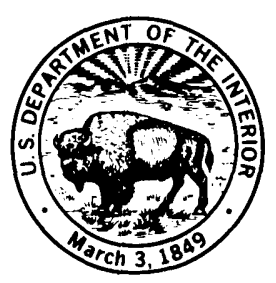




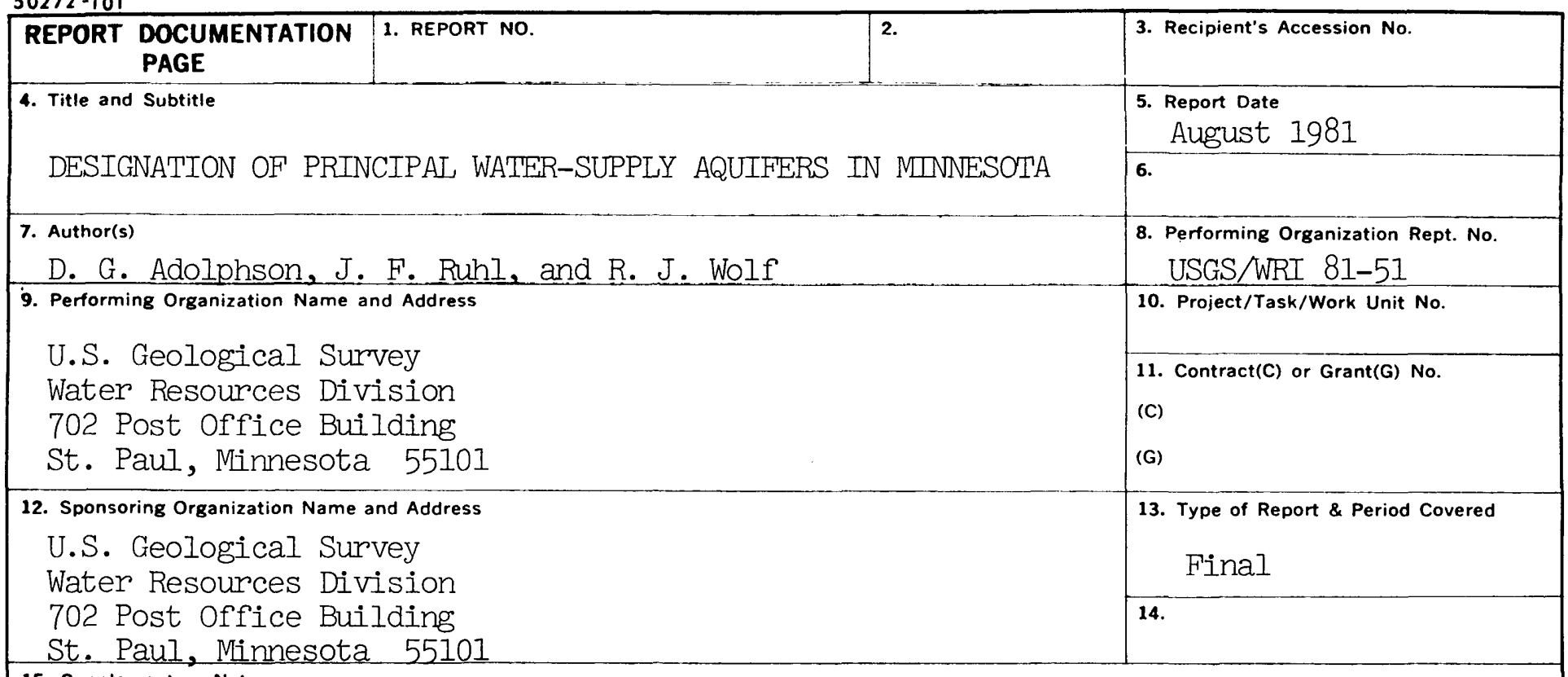

15. Supplementary Notes

Prepared in cooperation with the U.S. Environmental Protection Agency

\section{Abstract (Limit: 200 words)}

Fourteen aquifers, ranging from Quatemary to Precambrian in age, have been identified as the principal sources of water to wells in Minnesota. Half the municipal population and nearly all the rural population depend on water from these aquifers. Buried and surficial sand and gravel aquifers of Quaternary age occur in nearly all areas of the State and are composed of outwash, beach-ridge, valley-train, and ice-contact deposits. Cretaceous aquifers, absent in the northeast, are nearly continuous in the western half, and are thin or discontinuous in the central and southeast areas. Sandstone and carbonate rocks of Paleozoic and late Precambrian age in southeastern and northwestern Minnesota comprise the Cedar Valley-Maquoketa-Dubuque-Galena, Red River-Winnipeg, St. Peter, Prairie du Chien-Jordan, Franconia-Ironton-Galesville, and Mount Simon-Hinckley-Fond du Lac aquifers. Aquifers of early Precambrian age occur in all but southeastern Minnesota and include the North Shore Volcanic Group, Sioux Quartzite, Proterozoic metasedimentary rocks, Biwabik Iron-formation, and undifferentiated Precambrian rocks.

The State's ground water generally contains less than 1,000 milligrams per liter of dissolved solids, except in the extreme southwest, northeast, and western areas. Mineralized water is present at depth throughout the State. Freshwater extends to depths of about 1,000 feet in the center of the Hollandale embayment and in the Twin Cities basin. Six principal water-quality types are present in the aquifers. Calcium magnesium bicarbonate type water, the most common, is generally present throughout the upper part of the ground-water system. 17. Document Analysis a. Descriptors

*Groundwater, *Water quality, Aquifers

b. Identifiers/Open-Ended Terms

Minnesota, Hollandale embayment, Twin Cities basin

c. COSATI Field/Group

18. Availability Statement

No restriction on distribution.

\begin{tabular}{|c|}
$\begin{array}{c}\text { 19. Security Class (This Report) } \\
\text { UNCLASSIFIED }\end{array}$ \\
\hline $\begin{array}{c}\text { 20. Security Class (This Page) } \\
\text { UNCLASSIFIED }\end{array}$ \\
\hline
\end{tabular}

21. No. of Pages 24

22. Price OPTIONAL FORM 272 (4-77) (Formerly NTIS-35) Department of Commerce 
DESIGNATION OF PRINCIPAL WATER-SUPPLY AQUIFERS IN MINNESOTA

By D. G. Adolphson, J. F. Ruhl, and R. J. Wolf

U.S. GEOLOGICAL SURVEY

Water-Resources Investigations 81-51

Prepared in cooperation with the

U.S. ENVIRONMENTAL PROTECTION AGENCY

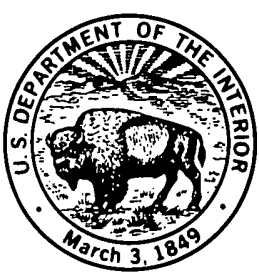


UNITED STATES DEPARTMENT OF THE INTERIOR

JAMES G. WATT, Secretary

GEOLOGICAL SURVEY

Dallas L. Peck, Director

For additional information write to:

District Chief

U.S. Geological Survey

702 Post Office Building

St. Paul, Minnesota 55101 


\section{CONTENTS}

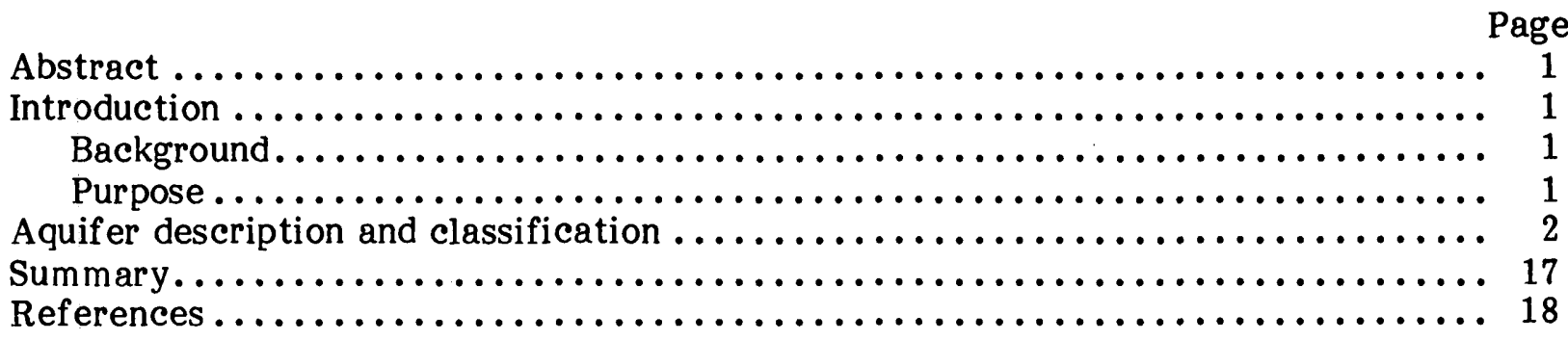

Figures 1-3. Maps showing extent of:

1. Surficial Quaternary aquifers $\ldots \ldots \ldots \ldots \ldots \ldots \ldots \ldots \ldots$

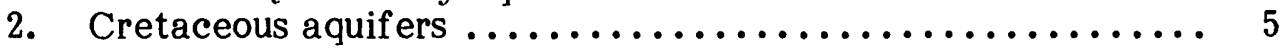

3. Paleozoic and late Precambrian aquifers ............. 6

4. Early Precambrian aquif ers ..................... 7

5. Map showing generalized distribution of mean dissolved-solids concentration of ground water used in Minnesota .......... 8

6. Map showing quality of shallowest mineralized ground water

within 500 feet of land surface ...................... 9

7-9. Maps showing dominant water-quality types in:

7. Quaternary aquif ers $\ldots \ldots \ldots \ldots \ldots \ldots \ldots \ldots \ldots \ldots \ldots 11$

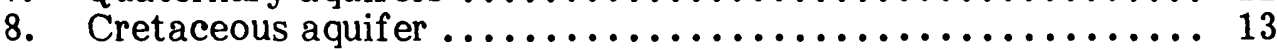

9. Paleozoic and Precambrian aquifers $\ldots \ldots \ldots \ldots \ldots \ldots \ldots 14$

\section{TABLES}

Table 1. Generalized stratigraphic and hydrogeologic units of principal aquifers in Minnesota

\section{CONVERSION FACTORS}

Multiply inch-pound unit

foot $(f t)$

gallon per minute (gal/min)
$\underline{B y}$

0.3048

0.06309
To obtain SI (metric) unit

meter $(\mathrm{m})$

liter per second $(\mathrm{L} / \mathrm{s})$ 
. 


\title{
DESIGNATION OF PRINCIPAL WATER-SUPPLY AQUIFERS IN MINNESOTA
}

By D. G. Adolphson, J. F. Ruhl, and R. J. Wolf

\begin{abstract}
Fourteen aquifers, ranging from Quaternary to Precambrian in age, have been identified as the principal sources of water to wells in Minnesota. Half the municipal population and nearly all the rural population depend on water from these aquifers. Buried and surficial sand and gravel aquifers of Quaternary age occur in nearly all areas of the State and are composed of outwash, beach-ridge, valley-train, and ice-contact deposits. Cretaceous aquifers, absent in the northeast, are nearly continuous in the western half, and are thin or discontinuous in the central and southeast areas. Sandstone and carbonate rocks of Paleozoic and late Precambrian age in southeastern and northwestern Minnesota comprise the Cedar Valley-Maquoketa-Dubuque-Galena, Red RiverWinnipeg, St. Peter, Prairie du Chien-Jordan, Franconia-Ironton-Galesville, and Mount Simon-Hinckley-Fond du Lac aquifers. Aquifers of early Precambrian age occur in all but southeastern Minnesota and include the North Shore Volcanic Group, Sioux Quartzite, Proterozoic metasedimentary rocks, Biwabik Iron-formation, and undifferentiated Precambrian rocks.

The State's ground water generally contains less than 1,000 milligrams per liter of dissolved solids, except in the extreme southwest, northeast, and western areas. Mineralized water is present at depth throughout the State. Freshwater extends to depths of about 1,000 feet in the center of the Hollandale embayment and in the Twin Cities basin. Six principal water-quality types are present in the aquifers. Calcium magnesium bicarbonate type water, the most common, is generally present throughout the upper part of the ground-water system.
\end{abstract}

\section{INTRODUCTION}

\section{Background}

The U.S. Environmental Protection Agency's (EPA) underground injection control (UIC) program, as authorized by the Safe Drinking Water Act, Public Law 93-523, is aimed to protect the quality of drinking water from contamination by fluids injected underground. The Environmental Protection Agency has consequently asked the U.S. Geological Survey to make a study of the baseline water quality of Minnesota's aquifers in order to assess future impacts of fluid injection on the ground-water resources of the State. The study is based primarily on data contained in U.S. Geological Survey reports, hydrogeologic maps of the Minnesota Geological Survey, and water-quality data from Environmental Protection Agency STORET and U.S. Geological Survey WATSTORE computer data bases.

\section{Purpose}

The purpose of this report is to describe the general quality and quantity of water in the principal water-supply aquifers in Minnesota. The scope of the report is to present a series of maps of the aquifers with discussions of (1) the areal extent, (2) dominant 
water-quality types, and (3) the distribution of mean dissolved-solids concentrations. This information will be used to provide a framework for the organization and preparation of a series of reports on the hydrogeology and water quality of the aquifers.

\section{AQUIFER DESCRIPTION AND CLASSIFICATION}

The quality and quantity of water in Minnesota's aquifers have been broadly outlined in several previous studies: Information from the following reports is used to describe the State's aquifers. The U.S. Geological Survey's Hydrologic Atlas series provides a considerable amount of hydrogeologic information about the principal aquifers in the State. Walton (1975), Lindholm and Norvitch (1976), and Kanivetsky (1979) summarize ground-water resources of Minnesota. Water resources in the Twin Cities are described in Norvitch and others (1974). Information on the geology, lithology, extent, and origin of aquifers is summarized in Schwartz and Thiel (1963), Wright and Ruhe (1965), Sims (1970), Sims and Morey (1972), and Morey (1976). Data on the quality of water are obtained from Rodis and Schneider (1960), Feth and others (1965), Maclay and Winter (1967), Winter (1974) and the Hydrologic A tlas series.

Fourteen aquifers, ranging from Quaternary to Precambrian in age, are the major source of water to wells in Minnesota. These aquifers supply half the municipal population and nearly all the rural population with water. The aquifers occur in two broad geologic categories: (1) glacial deposits, and (2) bedrock (table 1).

Most glacial aquifers consist of sand and gravel deposits called outwash, which is the material washed out of glaciers by melt waters. Outwash occurs both as surficial deposits and, because of repeated glaciations in the State, as buried deposits. Other surficial aquifers also occur as alluvial, valley-fill, ice-contact, and beach-ridge deposits (fig. 1). The buried deposits, which underlie one or more layers of till, are just as important as the surficial aquifers because in many areas they are the only source of water.

The bedrock aquifers are sedimentary formations and crystalline rocks. The sedimentary formations consist of sandstone, dolomite, and limestone that were laid down in seas that covered Minnesota before the glacial period (figs. 2 and 3). The crystalline bedrock makes up the basement complex in the State (fig. 4). Although only small yields of water are available to wells completed in the crystalline rocks, they are important locally where no other source of water is available. Yields of wells discussed in this report are short-term yields to single wells and do not indicate the aquifer's ability to supply water for a long period.

Most of the water in the State's aquifers is fresh (defined as having dissolved-solids concentrations of less than $1,000 \mathrm{mg} / \mathrm{L}$ ). Dissolved-solids concentration is widely used to compare waters from different places. Lines of equal dissolved-solids concentration in figure 5 are based on mean values computed for each county using samples collected from approximately 3,000 wells (Pettyjohn and others, 1979). The construction of the map is based on values representative of all aquifers used in the counties. In most cases more than one aquifer is involved and, in some cases, as many as two or three. Consequently, the map does not reflect vertical variability in water quality among the different aquifers. The map shows that the dissolved solids generally increase from east to west in the State. Figure 6 shows ranges of dissolved-solids concentration of the shallowest mineralized water (greater than $1,000 \mathrm{mg} / \mathrm{L}$ dissolved solids) within 500 feet of land surface. The map shows that mineralized water is present in the northeastern and southwestern parts of the State and along the west boundary. Elsewhere, mineralized water underlies fresh water at some depth greater than $500 \mathrm{feet}$. For example, mineralized water is as deep as 1,000 feet in places near the center of the Hollandale embayment in southeastern Minnesota and in the Twin Cities basin. 
Table 1.-Generalized stratigraphic and hydrogeologic units of principal aquifers in Minnesota

\begin{tabular}{|c|c|c|c|c|}
\hline \multicolumn{2}{|r|}{$\begin{array}{c}\text { Erathem } \\
\text { and } \\
\text { Eonothem }\end{array}$} & System & Stratigraphic unit & Hydrogeologic unit \\
\hline \multirow{2}{*}{\multicolumn{2}{|c|}{ Cenozoic }} & \multirow{2}{*}{ Quaternary } & \multirow{2}{*}{ Drift } & Surficial sand and gravel \\
\hline & & & & Buried sand and gravel \\
\hline & Mesozoic & Cretaceous & $\begin{array}{l}\text { Cretaceous rocks, } \\
\text { undifferentiated }\end{array}$ & Cretaceous \\
\hline & \multirow{8}{*}{ Paleozoic } & Devonian & Cedar Valley Limestone & \multirow[b]{2}{*}{ Upper carbonate } \\
\hline & & \multirow{4}{*}{ Ordovician } & $\begin{array}{l}\text { Maquoketa Shale } \\
\text { Dubuque Formation } \\
\text { Galena Dolomite }\end{array}$ & \\
\hline & & & $\begin{array}{l}\text { Red River Formation } \\
\text { Winnipeg Formation }\end{array}$ & Red River-Winnipeg \\
\hline & & & \multirow{2}{*}{$\begin{array}{l}\text { St. Peter Sandstone } \\
\text { Prairie du Chien Group }\end{array}$} & St. Peter \\
\hline & & & & \multirow[t]{2}{*}{ Prairie du Chien-Jordan } \\
\hline & & \multirow{3}{*}{ Cambrian } & Jordan Sandstone & \\
\hline & & & $\begin{array}{l}\text { Franconia Formation } \\
\text { Ironton Sandstone } \\
\text { Galesville Sandstone } \\
\end{array}$ & $\begin{array}{l}\text { Franconia-Ironton- } \\
\text { Galesville }\end{array}$ \\
\hline & & & Mount Simon Sandstone & \multirow{2}{*}{$\begin{array}{l}\text { Mount Simon-Hinckley- } \\
\text { Fond du Lac }\end{array}$} \\
\hline \multirow{6}{*}{ 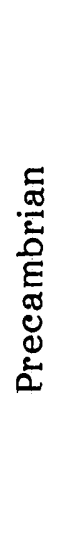 } & \multirow{5}{*}{ Proterozoic } & & $\begin{array}{l}\text { Hinckley Sandstone } \\
\text { Fond du Lac Formation }\end{array}$ & \\
\hline & & & $\begin{array}{c}\text { North Shore Volcanic } \\
\text { Group }\end{array}$ & North Shore Volcanic \\
\hline & & & Sioux Quartzite & Sioux Quartzite \\
\hline & & & $\begin{array}{l}\text { Proterozoic metasedi- } \\
\text { mentary rocks }\end{array}$ & $\begin{array}{l}\text { Proterozoic metasedi- } \\
\text { mentary }\end{array}$ \\
\hline & & & Biwabik Iron-formation & Biwabik Iron-formation \\
\hline & $\begin{array}{l}\text { Proterozoic } \\
\text { and older }\end{array}$ & & $\begin{array}{l}\text { Precambrian rocks, } \\
\text { undifferentiated }\end{array}$ & $\begin{array}{l}\text { Precambrian rocks, } \\
\text { undifferentiated }\end{array}$ \\
\hline
\end{tabular}




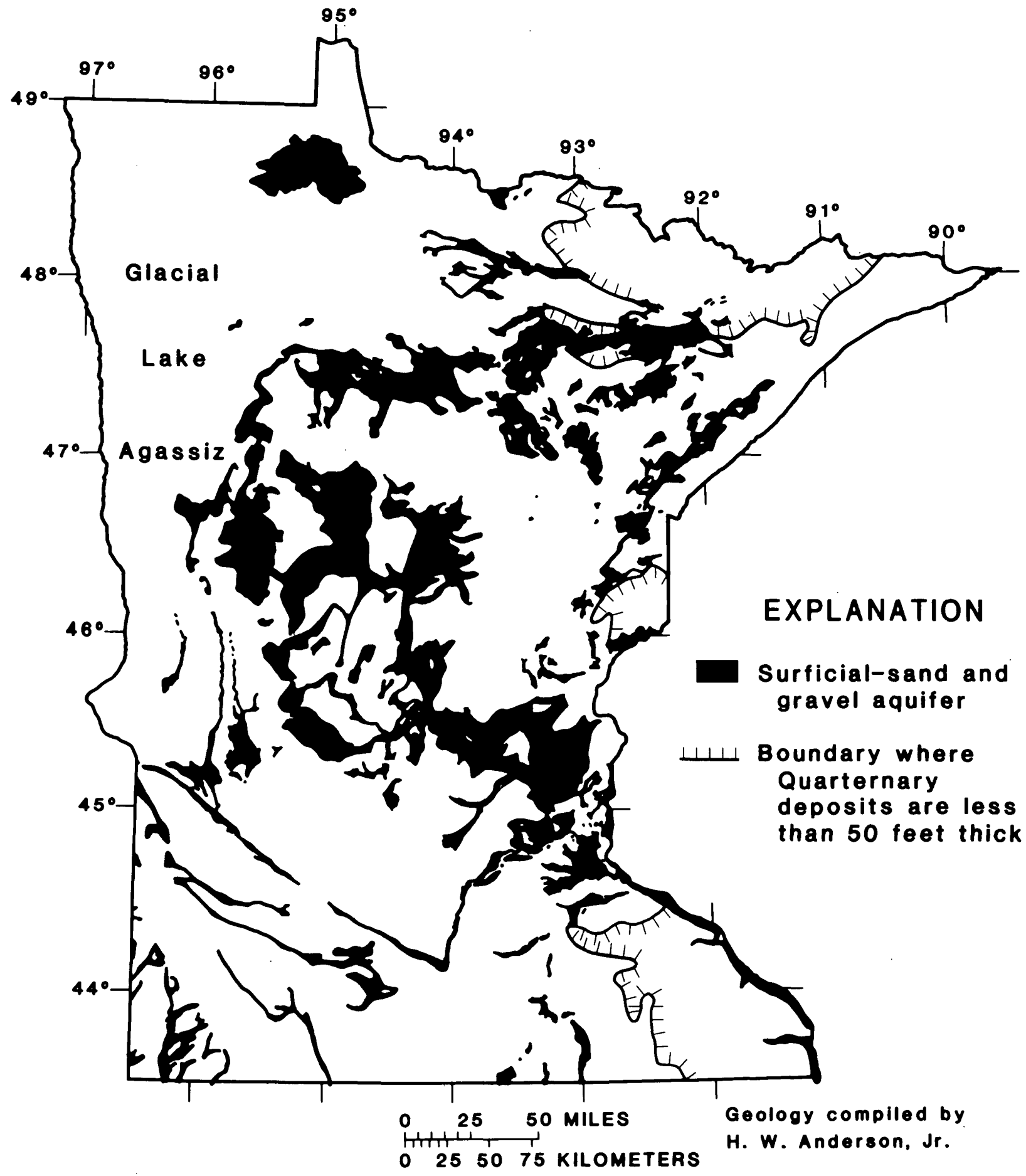

Figure 1.--Extent of surficlal Quarternary aquifers 


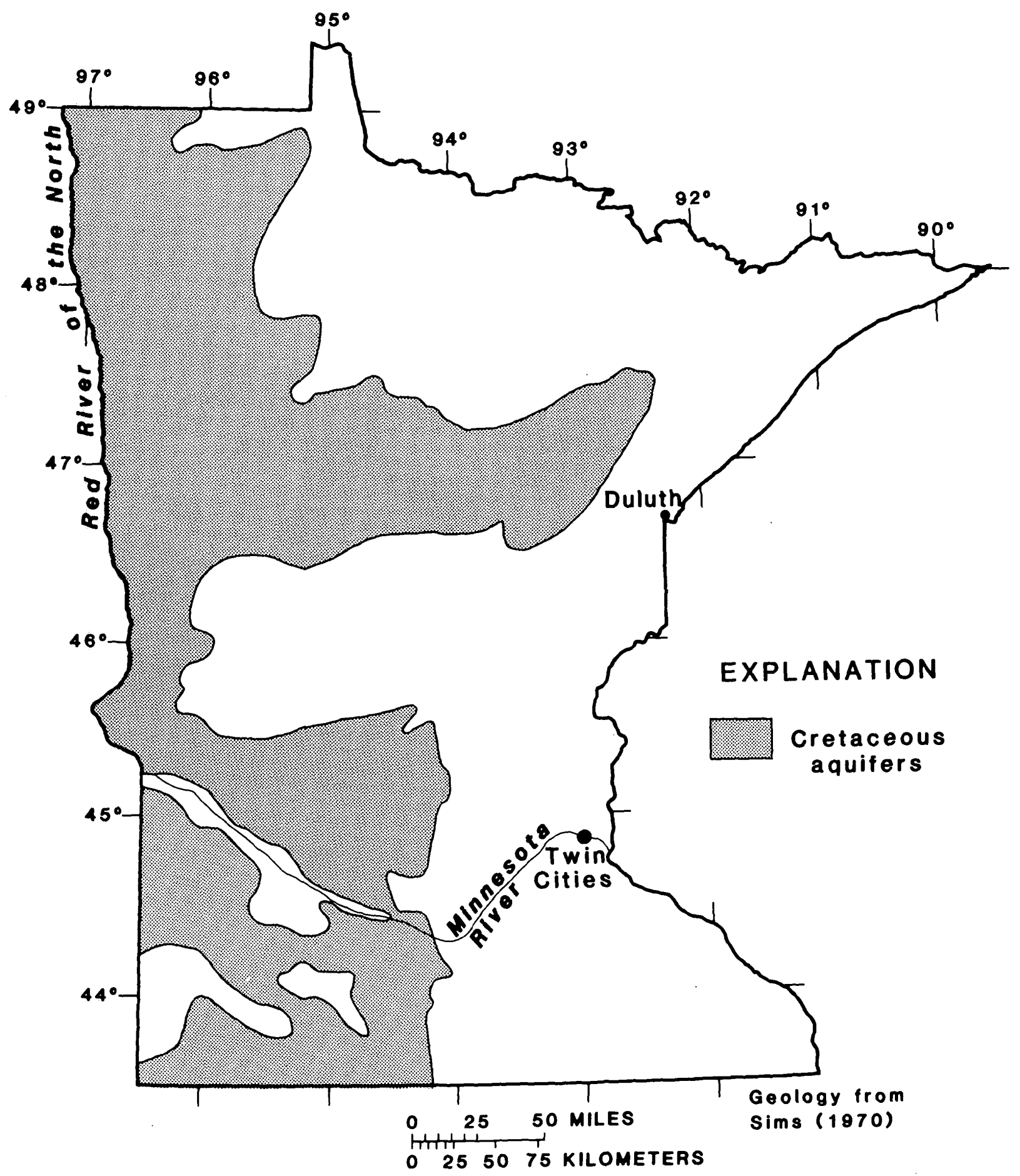

Figure 2.-.Extent of Cretaceous aquifers 


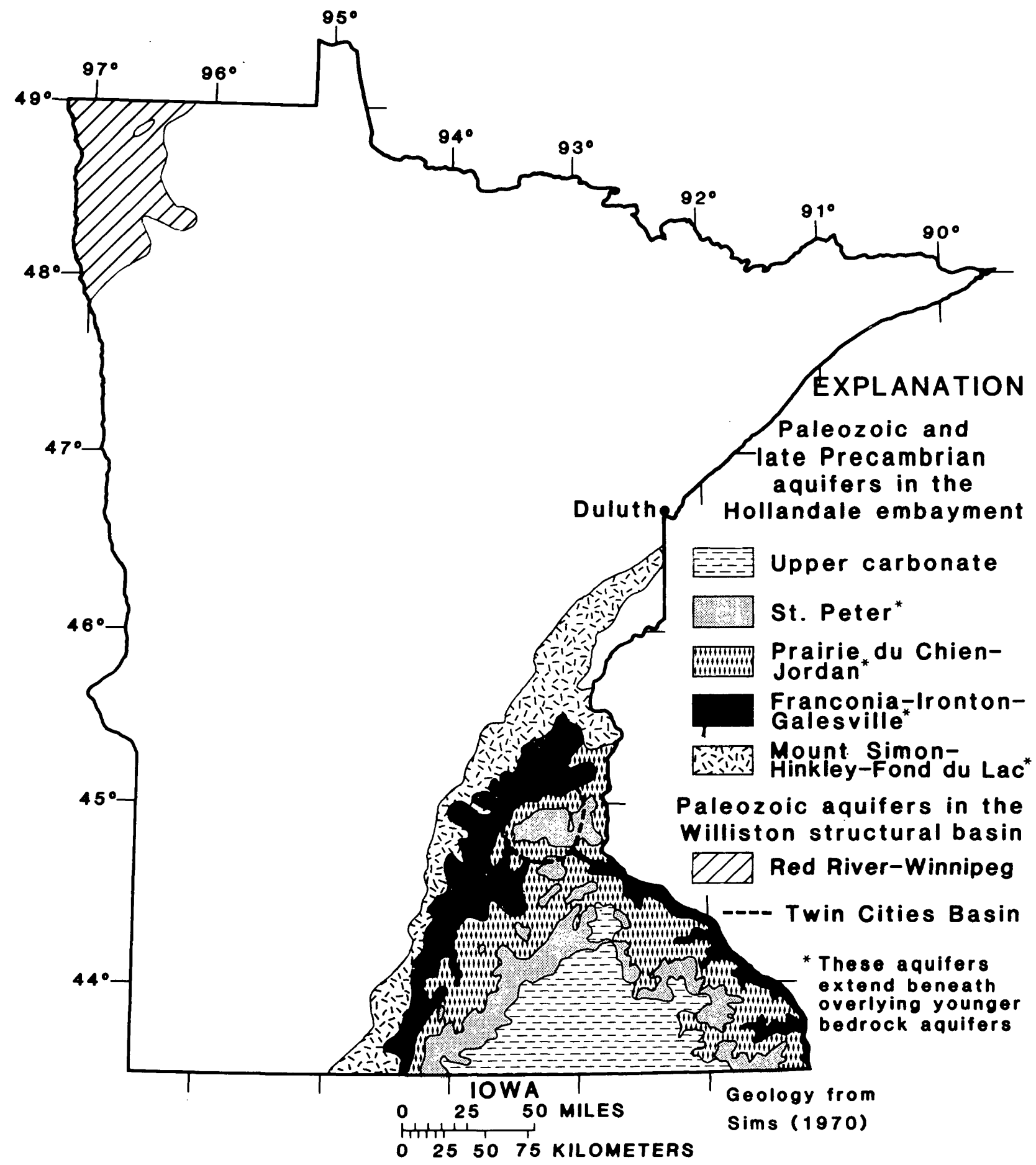

Figure 3.--Extent of Paleozoic and late Precambrian aquifers 


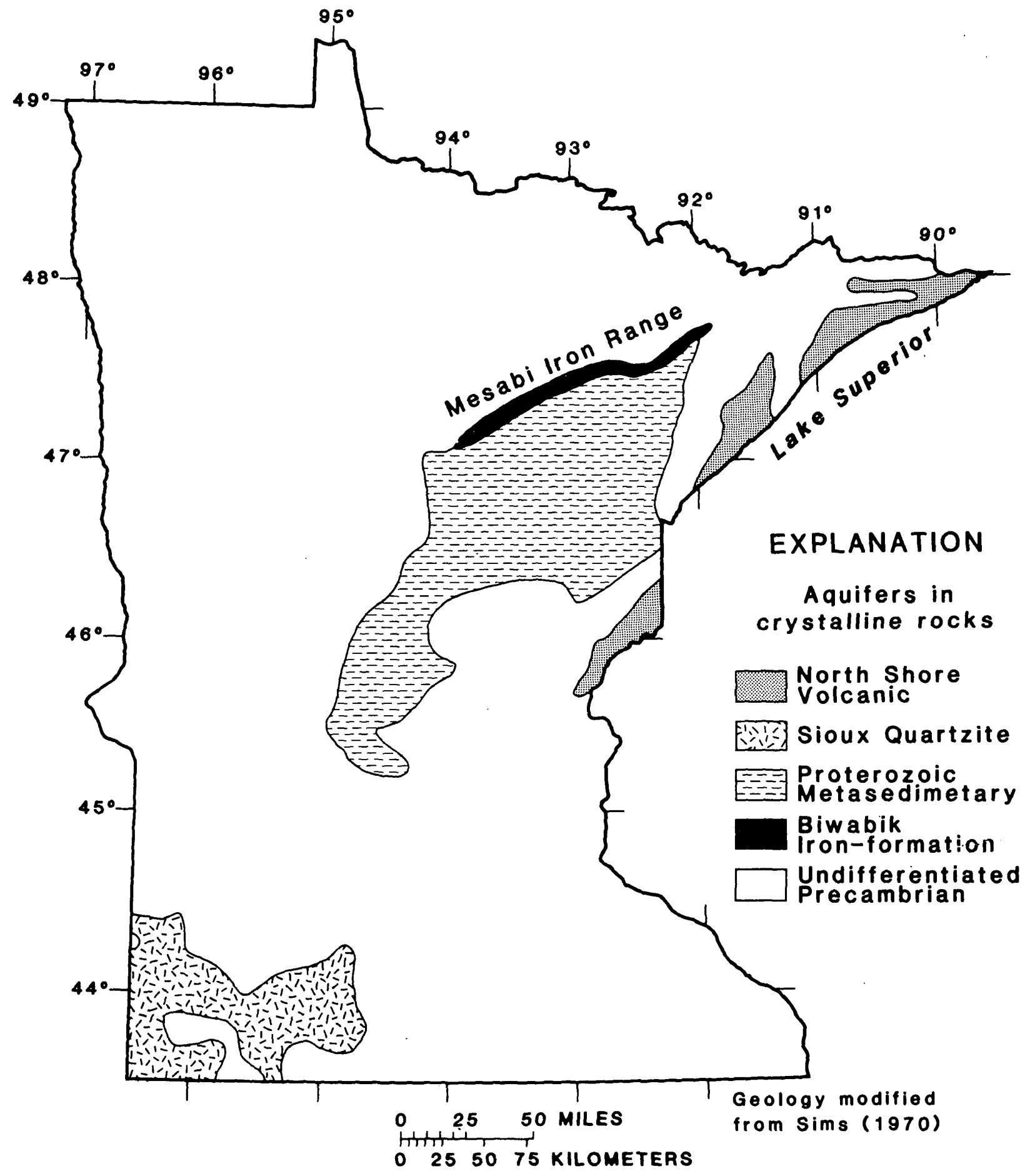

Figure 4.--Extent of early Precambrian aquifers 


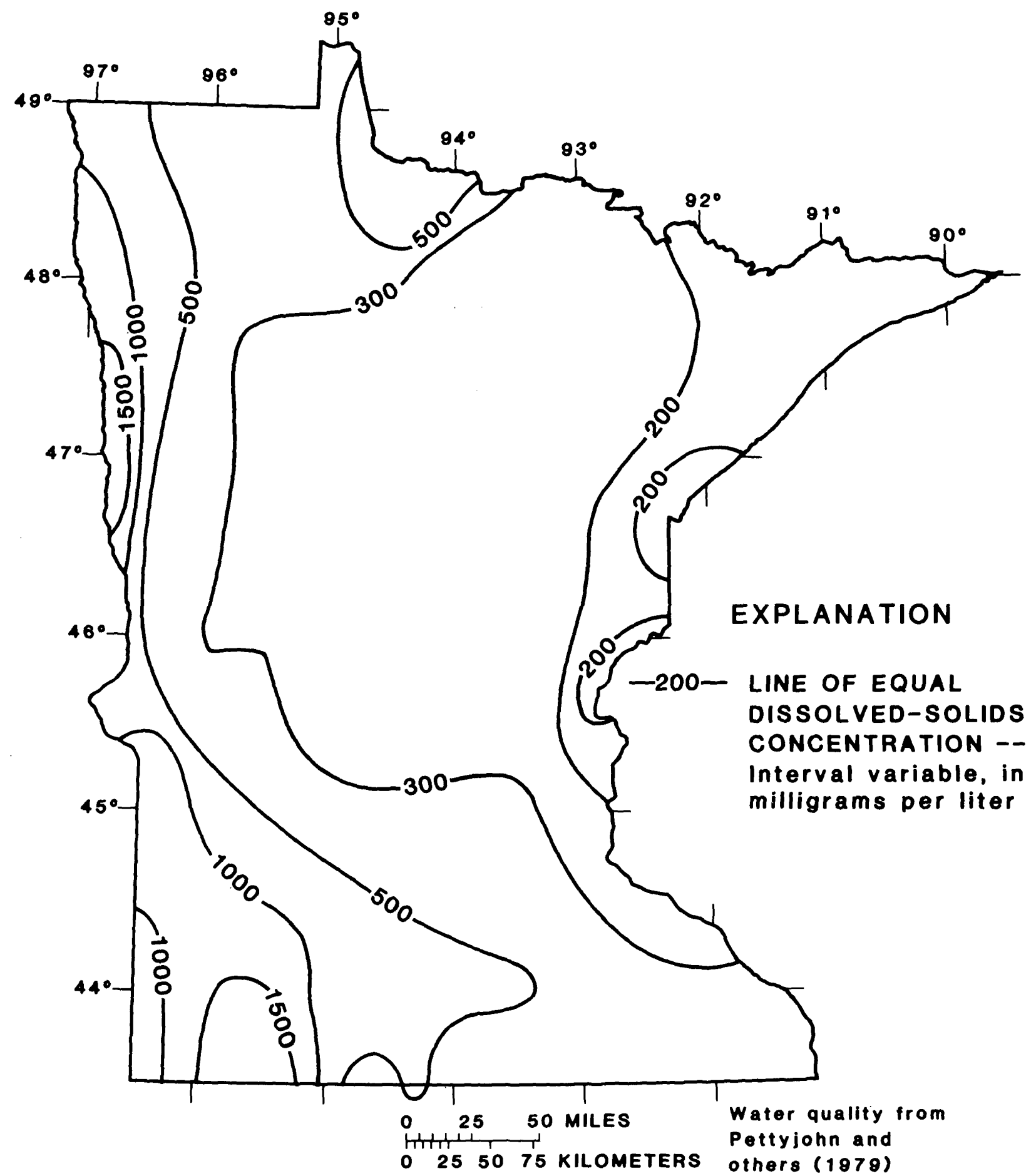

Flgure 5.--Generallzed distribution of mean dissolved-solids concentration of ground water used in Minnesota 


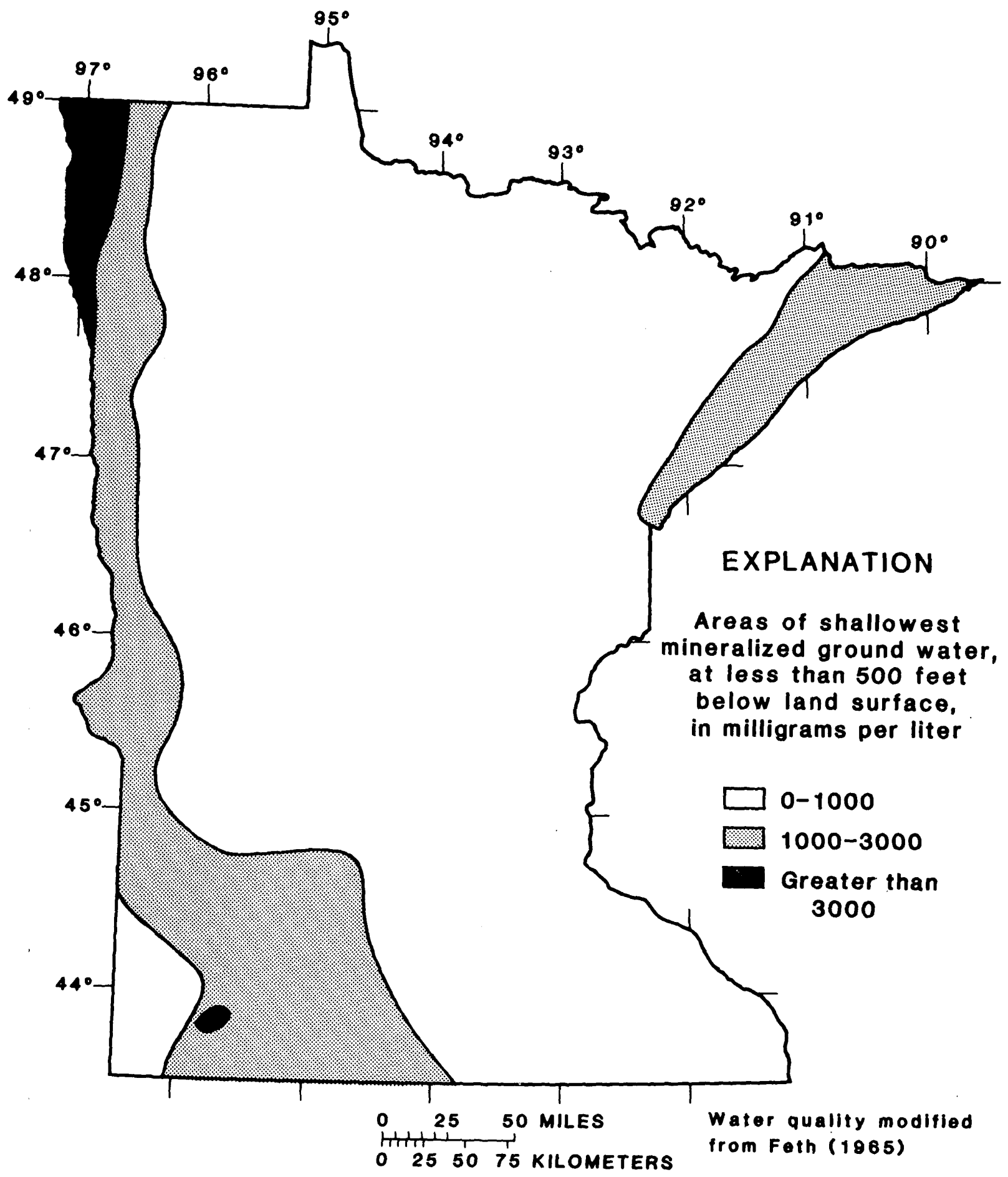

Flgure 6.--Quallty of shallowest minerallzed ground water within 500 feet of land surface 
Ground water is commonly classified by chemical type on the basis of relative concentrations in milliequivalents of principal cations and anions. This classification provides the basis for grouping waters of similar types and for evaluating chemical mechanisms that affect water quality. Different water-quality types may exist in proximity, varying both vertically and laterally among different aquifers or even within the same aquifer. Six principal water-quality types are present in the aquifers of the State. Ground water in Minnesota is predominately of the calcium magnesium bicarbonate type. This water type generally occurs in recharge areas and, most of ten, in the upper part of the ground-water system.

The aquifer descriptions given below have been modified from classifications devised by the Minnesota Geological Survey (Kanivetsky, 1978) and the U.S. Geological Survey (Hult, 1979). They are assigned numbers from 1 to 14 in the order from the youngest to oldest.

1. Surficial sand and gravel aquifers: These aquifers cover about one-third of the State and are comprised of alluvial outwash, beach-ridge, valley-train, and icecontact deposits (fig. 1). Extensive outwash deposits are a significant source of ground water in central Minnesota. The aquifers are unconfined, and well yields range from 10 to $3,000 \mathrm{gal} / \mathrm{min}$ on a short-term basis. Sustained yields are as much as $1,000 \mathrm{gal} / \mathrm{min}$ in places. The thickness of the deposits, which consist of fine to coarse sand and gravel, is generally less than 100 feet, but may reach several hundred feet in places. Although water supplies have been only slightly to moderately developed from surficial aquifers in most of the State, there is a possibility of overdevelopment in heavily irrigated areas. Dissolved-solids concentrations are generally less than $500 \mathrm{mg} / \mathrm{L}$; maximum concentrations are about $1,000 \mathrm{mg} / \mathrm{L}$. Hardness ranges from 200 to $400 \mathrm{mg} / \mathrm{L}$. Generally, iron and manganese concentrations are greater than $1 \mathrm{mg} / \mathrm{L}$, and, locally, nitrates are as much as $30 \mathrm{mg} / \mathrm{L}$. Calcium magnesium bicarbonate is the dominant water type (fig. 7).

2. Buried sand and gravel aquifers: These aquifers can occur in nearly all areas of the State except where the drift is thin or absent such as in the northeast and southeast (fig. 1). The aquifers consist of discontinuous lenses of fine to coarse sand and gravel that are isolated from one another by till. Most lenses are less than 10 feet thick, but they may be as much as 150 feet thick locally. Where present, the lenses occur at depths ranging from a few feet below land surface to the base of the drift. These aquifers are generally confined, and well yields range from about 10 to $1,000 \mathrm{gal} / \mathrm{min}$. Buried aquifers are the major source of water for municipal and farm wells in the central and southwest parts of the State, but are only slightly developed in other areas. The aquifers may have good potential for development in areas where the sand and gravel fill valleys in the bedrock surface. Dissolved-solids concentrations are generally less than $1,000 \mathrm{mg} / \mathrm{L}$; maximum concentrations are about $2,000 \mathrm{mg} / \mathrm{L}$. The hardness of the water ranges from 300 to $1,200 \mathrm{mg} / \mathrm{L}$. Iron and manganese concentrations are commonly troublesome. The dominant water type is calcium magnesium bicarbonate, but in the southwest and northwest where the buried aquifers are underlain by Cretaceous rocks, calcium magnesium bicarbonate sulfate and calcium magnesium chloride water types are present (fig. 7). 


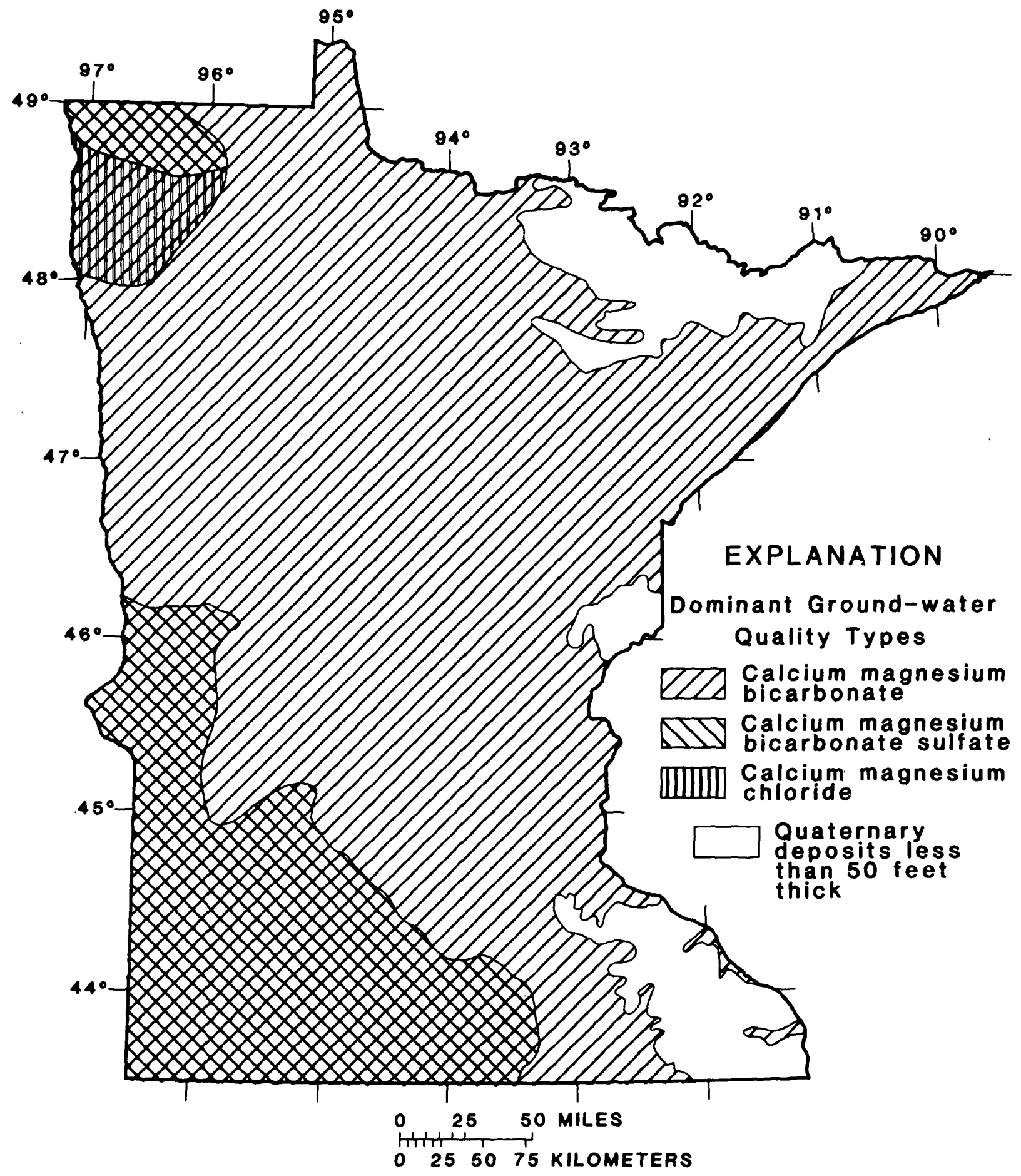

Figure 7.--Dominant water quality types in Quaternary aquifers 
3. Cretaceous aquifer: These rocks generally consist of gray, soft $t_{2}$ argillaceous shale that contains sand beds. The deposits are nearly continuous in the western half of the State, thin or discontinuous in the central and southeast, and absent in the northeast (fig. 2). The aquifer is not widely used except where drift aquifers are absent or where well yields are poor. The Cretaceous aquifer is a major source of water locally southwest of the Minnesota River. Most water use is for farm supplies and pumping rates usually do not exceed $10 \mathrm{gal} / \mathrm{min}$. Ground water in the aquifer is confined and wells yield as much as $25 \mathrm{gal} / \mathrm{min}$ where the sedimentary rocks are relatively thick and the sand is more than 10 feet thick. However, the potential for development of large municipal and industrial water supplies is poor.

Five water types occur in the Cretaceous aquifer (fig. 8). Sodium bicarbonate type water occurs at depths in the northwest. Calcium infiltrates into the Cretaceous rocks from overlying drift aquifers and is removed by cation exchange for sodium. Dissolved-solids concentrations are generally between 500 and $1,500 \mathrm{mg} / \mathrm{L}$ and hardness ranges from 25 to $200 \mathrm{mg} / \mathrm{L}$. Sodium chloride type water is common in the extreme west. Cretaceous and Paleozoic aquifers in the Williston structural basin of North and South Dakota are the major sources of sodium chloride type water in Minnesota. Dissolved-solids concentrations range from 2,000 to $4,000 \mathrm{mg} / \mathrm{L}$. Sodium chloride type water is also common in the Cretaceous sedimentary rocks southwest of the Minnesota River. Locally, chloride concentrations are as much as $2,000 \mathrm{mg} / \mathrm{L}$. The water is soft, ranging from less than 20 to $120 \mathrm{mg} / \mathrm{L}$. Sodium sulfate type water also occurs southwest of the Minnesota River. Sulfate type water in the drift may result from mixing with the sodium chloride type water or from calcium magnesium bicarbonate sulfate type water in the Cretaceous aquifer undergoing cation exchange in clayey deposits. Dissolved-solids concentrations are as much as $6,000 \mathrm{mg} / \mathrm{L}$. Calcium magnesium bicarbonate type water occurs northeast of the Minnesota River.

4. Cedar Valley-Maquoketa-Dubuque-Galena aquifer: The aquifer (hereafter called upper carbonate aquifer) is composed mainly of limestone, dolomite, and dolomitic limestone and is the youngest of a series of sedimentary Paleozoic formations deposited in the Hollandale embayment of southeastern Minnesota (fig. 3). This aquifer, which extends about 80 miles northward into Minnesota from the lowa border, and the underlying aquifers make this area the most favorable part of the State for developing large water supplies. Wells in the upper carbonate aquifer are completed in solution channels, joints, and fissures. Yields range from 200 to $500 \mathrm{gal} / \mathrm{min}$ and are highly variable. The highest yields are obtained where wells penetrate the entire carbonate section. Water supplies have been slightly to moderately developed and there is excellent potential for additional development. However, the aquifer is extensively contaminated from agricultural wastes and other nonpoint sources. Concentrations of nitrate are generally higher than recommended limits in much of the area. Dissolved-solids concentrations range from 200 to $650 \mathrm{mg} / \mathrm{L}$ and hardness from 200 to $400 \mathrm{mg} / \mathrm{L}$. Locally, concentrations of iron are greater than $1 \mathrm{mg} / \mathrm{L}$. The water is a calcium magnesium bicarbonate type (fig. 9).

5. Red River-Winnipeg aquifer: This aquifer, which underlies several hundred feet of till and lake sediments of Glacial Lake Agassiz in the northwest corner of the State, is composed mainly of sandstone, limestone, and shale of Paleozoic age (fig. 3). The rocks extend westward into the Williston structural basin. Water is 


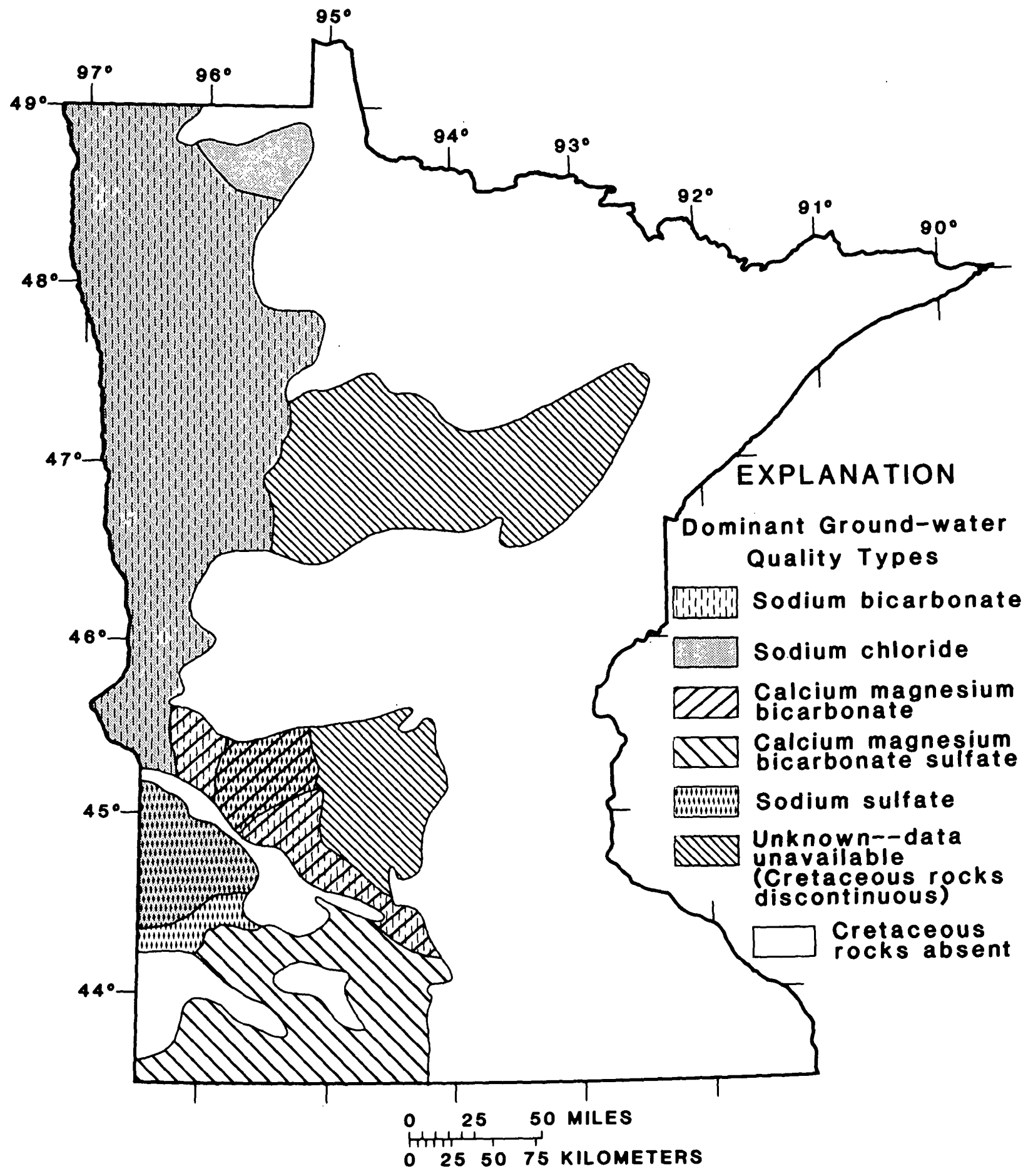

Figure 8.--Dominant water quality types in Cretaceous aquifers 


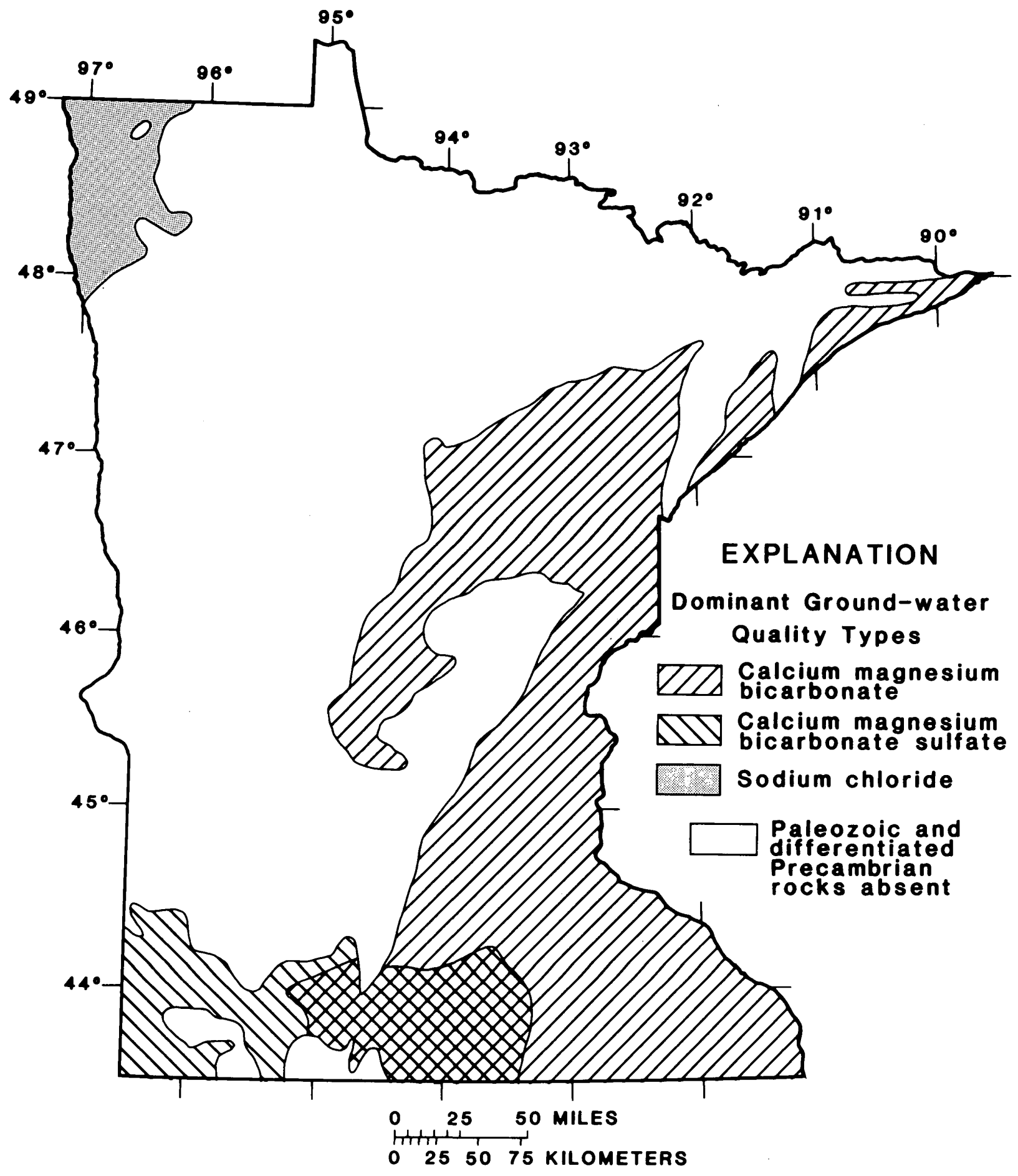

Figure 9.--Dominant water quality types in Paleozoic and Precambrian aquifers 
under confined conditions throughout most of the aquifer. Flows of $60 \mathrm{gal} / \mathrm{min}$ from artesian wells have been recorded, and yields to pumping wells may exceed several hundred gallons per minute from wells that penetrate the entire section. The aquifer, which has a great potential for large supplies, is seldom used because the water generally is not suitable for drinking. Water from the aquifer is highly mineralized. Dissolved-solids concentrations range from 5,000 to 60,000 $\mathrm{mg} / \mathrm{L}$. The water is a sodium chloride type (fig. 9).

6. St. Peter aquifer: The aquifer, a white, fine- to medium-grained sandstone, is part of the Paleozoic system in the Hollandale embayment of southeastern Minnesota (fig. 3), and extends as far north as the. Twin Cities basin. Water occurs under both confined and unconfined conditions. Because of greater water supplies in underlying aquifers and the discontinous areal extent of the aquifer in the Twin Cities area, the St. Peter is generally not used for public supplies. Yields generally range from 10 to $100 \mathrm{gal} / \mathrm{min}$ and yields of $1,000 \mathrm{gal} / \mathrm{min}$ have been reported locally. Dissolved-solids concentrations range from 100 to $600 \mathrm{mg} / \mathrm{L}$ and hardness from 200 to $400 \mathrm{mg} / \mathrm{L}$. Calcium magnesium bicarbonate type water (fig. 9) generally occurs in the aquifer.

7. Prairie du Chien-Jordan aquifer: The aquifer is composed mainly of dolomite and sandstone and is the major aquifer in southeastern Minnesota (fig. 3). Karstic conditions at the surface are common in the extreme southeast where the drift is thin. Water supplies from the aquifer have been slightly to moderately developed in the southeast and highly developed in the Twin Cities where it provides about 75 percent of the annual ground-water supply. Wells yield as much as 2,400 $\mathrm{gal} / \mathrm{min}$ from the Jordan Sandstone and 1,800 gal/min from the Prairie du Chien. Wells completed in both units of the aquifer yield as much as $2,700 \mathrm{gal} / \mathrm{min}$ in the Twin Cities basin. In the southeast, well yields generally range from 300 to 600 $\mathrm{gal} / \mathrm{min}$.. Dissolved-solids concentrations of 200 to $600 \mathrm{mg} / \mathrm{L}$, and hardness of 200 to $400 \mathrm{mg} / \mathrm{L}$, are similar to other aquifers in the Hollandale embayment. The water type is calcium magnesium bicarbonate (fig. 9). Locally, water from the aquifer has nitrate concentrations as much as $20 \mathrm{mg} / \mathrm{L}$ and iron and manganese concentrations greater than $1 \mathrm{mg} / \mathrm{L}$.

8. Franconia-Ironton-Galesville aquifer: This aquifer, which consists of very fine to coarse sandstone interbedded with shale, dolomitic sandstone, and dolomitic siltstone, is the fourth in the series of bedrock aquifers in the Hollandale embayment of the southeast. The Franconia is not a significant source of water regionally, but the Ironton-Galesville (sandstone) may be an important source outside the boundary of the Prairie du Chien-Jordan aquif er (fig. 3). Yields range from 40 to $400 \mathrm{gal} / \mathrm{min}$. Dissolved-solids concentrations $(200$ to $650 \mathrm{mg} / \mathrm{L})$ and water type (calcium magnesium bicarbonate) are similar to other aquifers in the Hollandale embayment (fig. 9). Locally, iron and manganese concentrations are greater than $1 \mathrm{mg} / \mathrm{L}$.

9. Mount Simon-Hinckley-Fond du Lac aquifer: The aquifer comprises a thick sequence of sandstone, siltstone, and shale that underlies all the southeast part of Minnesota as far north as Duluth (fig. 3). It is an important aquifer in the Hollandale embayment and in the Twin Cities metropolitan area where it supplies about 15 percent of the ground water used. Withdrawals increase significantly north of the Twin Cities. Yields to wells are generally about $500 \mathrm{gal} / \mathrm{min}$ but, locally, yields may be as much as $2,000 \mathrm{gal} / \mathrm{min}$. A long-term cone of depression 
has developed in the Twin Cities metropolitan area. North of the Twin Cities, the aquifer will support additional moderate development. Dissolved-solids concentrations are slightly lower than in water from other aquifers in the Hollandale embayment, ranging from about $100 \mathrm{mg} / \mathrm{L}$ in the north to as much as $2,400 \mathrm{mg} / \mathrm{L}$ in the south. Dominant water type is calcium magnesium bicarbonate (fig. 9); sodium chloride type water occurs at depth in the southeast. The aquif er locally has concentrations of iron and manganese greater than $1 \mathrm{mg} / \mathrm{L}$.

10. North Shore Volcanic aquifer: This aquifer, the major bedrock aquifer along the north shore of Lake Superior, is a series of basaltic lava flows and interbedded sedimentary rocks (fig. 4). Water is generally obtained from the upper 300 to 400 feet where fractures and weathering are extensive. Yields to wells are generally less than $25 \mathrm{gal} / \mathrm{min}$, but locally are as much as $100 \mathrm{gal} / \mathrm{min}$. Many wells near the Lake Superior shore flow. The aquifer is moderately developed for rural and public supply. Quality of the water is highly variable ranging from good to highly mineralized. Dissolved solids range from 100 to $50,000 \mathrm{mg} / \mathrm{L}$ but most are less than $1,300 \mathrm{mg} / \mathrm{L}$. Hardness is as much as $28,000 \mathrm{mg} / \mathrm{L}$ but most hardness is less than $400 \mathrm{mg} / \mathrm{L}$. The water is predominantly of the calcium magnesium bicarbonate type (fig. 9), but sodium chloride type water occcurs locally.

11. Sioux Quartzite aquifer: This aquifer underlies most of southwest Minnesota (fig. 4). Locally, it is an important aquifer, furnishing water to seven municipal and to numerous domestic and stock wells. It is a fairly reliable source of water when the wells are completed in fractured and weathered zones near land surface and (or) buried zones of porous and poorly cemented sandstone that are interbedded within the well-cemented quartzite. Yields range from 1 to $450 \mathrm{gal} / \mathrm{min}$ and, for the municipal wells, average about $100 \mathrm{gal} / \mathrm{min}$. The best quality water is where the aquifer underlies thin drift. Dissolved-solids concentrations are generally less than $900 \mathrm{mg} / \mathrm{L}$ and total hardness is less than $400 \mathrm{mg} / \mathrm{L}$. The water is calcium magnesium bicarbonate sulfate type (fig. 9).

12. Proterozoic metasedimentary aquifer: This aquifer consists of thinly bedded gray to black argillite that underlies drift and rocks of Cretaceous age in much of the north-central part of the State (fig. 4). Yields to wells are generally less than 20 $\mathrm{gal} / \mathrm{min}$, but yields of $30 \mathrm{gal} / \mathrm{min}$ can be obtained locally from wells completed in the fractured zone near the upper surface of the aquifer. The water is utilized for numerous domestic and some municipal supplies. The water is of the calcium magnesium bicarbonate type and contains much less iron, manganese, dissolved solids, and hardness than most water from Biwabik Iron-formation and drif $t$ aquifers in the area (fig. 9).

13. Biwabik Iron-formation aquifer: The aquifer, which is composed of ferruginous chert, underlies drift and crops out in north-central Minnesota (fig. 4). It yields little water to wells where the rocks have not been altered by faulting or leaching. In the altered zones associated with joints, faults, and solution channels, individual yields range from 250 to $750 \mathrm{gal} / \mathrm{min}$. Yields to wells are as much as $1,000 \mathrm{gal} / \mathrm{min}$ in highly fractured zones. The aquifer yields water to many municipal and industrial wells and is the most productive source of ground water in the Mesabi Iron Range. The water meets drinking-water standards for all chemical constituents, although hardness ranges from moderate to very hard and the water locally contains much iron, manganese, and silica. The dissolved-solids concentrations range from about 100 to $300 \mathrm{mg} / \mathrm{L}$. The water type is calcium magnesium bicarbonate (fig. 9). 
14. Precambrian aquifer: The aquifer, consisting of igneous and metamorphic rocks such as granite, greenstone, and slate, underlies the entire State (fig. 4). Although these rocks are a source of small water supplies in the southwest, central, and northeast parts of Minnesota, they are not usually considered an aquifer in the rest of the State. Yields are dependent on the occurrence of fractures, faults, and weathered zones, and generally increase where the bedrock is overlain by thick drift. Some wells are drilled several hundred feet into the rocks, so that the drilled hole serves as a reservoir. Yields generally range from 1 to 25 $\mathrm{gal} / \mathrm{min}$; locally, yields are as much as $150 \mathrm{gal} / \mathrm{min}$. Water is of ten similar in quality to that of overlying drift. Dissolved-solids concentrations are generally less than $300 \mathrm{mg} / \mathrm{L}$. Calcium magnesium bicarbonate type water is the most common in the aquif er (fig. 9).

\section{SUMMARY}

The principal underground sources of drinking water in Minnesota have been identified, and fourteen aquifers are designated for further evaluation and description. A series of reports on the hydrogeology, and water quality of the aquifers will be prepared.

Buried and surficial sand and gravel aquifers of Quaternary age are composed of outwash, beach-ridge, valley-train, and ice-contact deposits. The surficial aquifers cover about one-third of the State and buried sand and gravel aquifers underlie nearly all the State except where the drift is thin. Calcium magnesium bicarbonate is the dominant water type and dissolved solids are generally less than $1,000 \mathrm{mg} / \mathrm{L}$ for surficial aquifers and $2,000 \mathrm{mg} / \mathrm{L}$ for buried aquifers.

Cretaceous rocks consist of poorly consolidated sandstone, shale, and limestone. The rocks occur in the west half of the State, but are discontinuous in the southeast and central parts, and absent in the northeast. Common water-quality types are sodium chloride and calcium magnesium bicarbonate sulfate. Dissolved solids generally range from 500 to $2,000 \mathrm{mg} / \mathrm{L}$, but locally may be as much as $6,000 \mathrm{mg} / \mathrm{L}$ in the southwest part.

Sandstone and carbonate rocks of Paleozoic and late Precambrian age in southeastern and northwestern Minnesota comprise six aquifers: (1) Cedar Valley-MaquoketaDubuque-Galena (upper carbonate), (2) Red River-Winnipeg, (3) St. Peter, (4) Prairie du Chien-Jordan, (5) Franconia-Ironton-Galesville, and (6) Mount Simon-Hinckley-Fond du Lac. Water in the Paleozoic aquif er system in the southeast is mostly calcium magnesium bicarbonate type. Dissolved-solids concentrations range from 200 to $650 \mathrm{mg} / \mathrm{L}$. Sodium chloride type water predominates in the Red River-Winnipeg aquifer of northwestern Minnesota, where the dissolved solids range from 5,000 to $60,000 \mathrm{mg} / \mathrm{L}$.

Crystalline rocks of Precambrian age include the following aquifers: (1) North Shore Volcanic Group, (2) Sioux Quartzite, (3) Proterozoic metasedimentary rocks, (4) Biwabik Iron-formation, and (5) undifferentiated Precambrian rocks. The aquifers are located mainly in the southwestern and the northeastern parts of the State. Calcium magnesium bicarbonate type water is dominant in these aquifers, but calcium magnesium bicarbonate sulfate type water is present in the Sioux Quartzite and sodium chloride type water is present locally in the North Shore Volcanic Group. Dissolved solids range from 200 to $2,000 \mathrm{mg} / \mathrm{L}$. Locally, dissolved solids are as much as $50,000 \mathrm{mg} / \mathrm{I}$. 


\section{REFE RENCES}

Austin, G. S., 1972a, Paleozoic lithostratigraphy of southeastern Minnesota, in Sims, P. K., and Morey, G. B., (eds.), Geology of Minnesota: A centennial volume: Minnesota Geological Survey, p. 459-473.

1972b, Cretaceous rocks, in Sims, P. K., and Morey, G. B., eds., Geology of Minnesota: A centennial volume: Minnesota Geological Survey, p. 509-514.

Feth, J. H., and others, 1965, Preliminary map of the conterminous United States showing depth to and quality of shallowest ground water containing more than 1,000 parts per million dissolved solids: U.S. Geological Survey Hydrologic Investigation Atlas 199.

Hem, J. D., 1970, Study and interpretation of the chemical characteristics of natural water: U.S. Geological Survey Water-Supply Paper 1473, 363 p.

Hult, M. F., 1979, Design of a network for monitoring ground-water quality in Minnesota: U.S. Geological Survey Open-File Report 79-1164, 44 p.

Kanivetsky, Roman., 1978, Design of a ground-water sampling network for Minnesota: U.S. Department of Energy GJBX-1(78).

1979, Hydrogeologic map of Minnesota; Minnesota Geological Survey State Map Series S-2, 1:500,000.

Lindholm, G. F., and Norvitch, R. F., 1976, Ground water in Minnesota: U.S. Geological Survey Open-File Report 76-354, 100 p.

Maclay, R. W., and Winter, T. C., 1967, Geochemistry and ground-water movement in northwestern Minnesota: Ground Water, v. 5, no. 1, p. 11-19.

Morey, G. B., 1976, Geologic map of Minnesota: Minnesota Geological Survey Miscellaneous Map Series, Map M-24.

Norvitch, R. F., Ross, T. G., and Brietkrietz, Alex, 1974, Water resources outlook for the Minneapolis-St. Paul metropolitan area: Metropolitan Council of the Twin Cities area, 219 p.

Pettyjohn, W. A., Sudlick, J. R., Bain, R. C., and Lehr, J. H., 1979, A ground-water quality atlas of the United States: National Demonstration Water Project, 272 p.

Rodis, H. G., and Schneider, Robert, 1960, Occurrence of ground waters of low hardness and of high chloride content in Lyon County, Minnesota: U.S. Geological Survey Circular 423, 2 p.

Schwartz, G. N., and Thiel, G. A., 1963, Minnesota's rocks and waters: Minnesota Geological Survey Bulletin 37, 366 p.

Sims, P. K., 1970, Geological map of Minnesota: Minnesota Geological Survey Miscellaneous map 14. 
Sims, P. K., and Morey, G. B., eds., 1972, Geology of Minnesota: A centennial volume: Minnesota Geological Survey, 631 p.

Walton, W. C., 1975, Minnesota's water resources - a primer: Water Resources Research Center, University of Minnesota Public Reports. Series 2, 33 p.

Winter, T. C., 1974, The natural quality of ground water in Minnesota: Minnesota Department of Natural Resources Bulletin 26, 25 p.

Wright, H. E., Jr., and Ruhe, R. V., 1965, Glaciation of Minnesota and Iowa, in Wright, H.

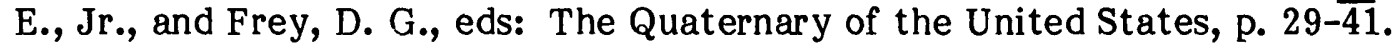

\& U. S. GOVERNMENT PRINTING OFFICE: 1982-565-781/186 